\title{
A TISZTA VÍZ MEMÓRIAZAVARAI, AVAGY HOGYAN NEM MÜKÖDHETNEK A HOMEOPÁTIÁS SZEREK
}

\section{MEMORY LOSS IN PURE WATER: OR HOW HOMEOPATHIC PRODUCTS DEFINITELY CANNOT WORK?}

\author{
Pusztai László \\ az MTA doktora, tudományos tanácsadó, MTA Wigner Fizikai Kutatóközpont \\ pusztai.laszlo@wigner.mta.hu
}

\begin{abstract}
ÖSSZEFOGLALÁS
A homeopátiás szerek "hatáselméletének" rövid ismertetése után bemutatom, hogy mit is jelentene mindez a víz mikroszkopikus szerkezetének szempontjából. Ezek után felidézem azt a kísérletet, amelyet a kétdimenziós infravörös spektroszkópia módszerével végeztek, és amely felső korlátot ad a víz szerkezetét meghatározó hidrogénkötések élettartamára. A kísérletek szerint a hidrogénkötés és ezzel együtt a vízmolekulák egy adott elrendeződése tiszta vízben legfeljebb a másodperc kevesebb mint egymilliárdod részéig maradhat állandó. Ez a kísérleti eredmény egyértelmúen jelzi a homeopátiás szerek feltételezett hatásmechanizmusának tarthatatlanságát.
\end{abstract}

\section{ABSTRACT}

Following a brief introduction to the "mode of action" of homeopathic products, it is described what all that would mean regarding the microscopic structure of water. Then, a two dimensional infrared spectroscopic experiment is recalled that was able to establish an upper limit for the lifetime of hydrogen bonds, which, in turn, determine the structure of water. According to these experiments, the hydrogen bond and therefore any given arrangement of water molecules can only last for less than one billionth of a second. This experimental result makes it evident that the assumed mode of action of homeopathic products is indefensible.

Kulcsszavak: homeopátia, vízszerkezet, hidrogénkötés, 2D infravörös spektroszkópia

Keywords: homeopathy, water structure, hydrogen bond, 2D infrared spectroscopy 


\section{BEVEZETŐ GONDOLATOK}

A homeopátia mint alternatív, természetes, holisztikus gyógyítás körüli vita manapság ismét fellángolni látszik, részben talán az Európai Akadémiák Tudományos Tanácsadó Testülete (EASAC) közelmúltbéli állásfoglalásától (EASAC, 2017) nem teljesen függetlenül. Az állásfoglalás (többek között) a következőket állítja: (a) a homeopátiás szerek hatásmechanizmusáról az azokat favorizálók által terjesztett tanok nem hozhatók összhangba megalapozott tudományos koncepciókkal, (b) a homeopátiás szerek hatásossága bizonyíthatóan nem terjed túl a placebohatáson. Ezen megállapításokkal teljes mértékben rezonál egy szintén közelmúltbeli, ám földrajzilag távoli helyen publikált jelentés (NHMRC, 2015): az Ausztrál Kormány Nemzeti Egészségügyi és Gyógyszerészeti Tudományos Tanácsa (National Health and Medical Research Council, NHMRC) átfogó forráselemzést végzett, amelynek eredményét röviden úgy lehet összefoglalni, hogy egyetlen megbízható összehasonlító vizsgálat sem tudott a placebohatáson túlmutató hatásosságról beszámolni egyetlen vizsgált tünetcsoport esetben sem. Miután a homeopátiás gyógyítás témaköre iránt érdeklődőknek számtalan információs forrás áll rendelkezésére (például a Wikipédia vontkozó oldalai vagy akár egy egészen friss MTA-videó [Fábián, 2017]), a továbbiakban a homeopátia komplex kérdéskörével általánosságban nem kívánok e helyt foglalkozni. Ehelyett egyetlen kérdésre, az ún. memória effektusra (lásd alább) koncentrálok.

\section{A HOMEOPÁTIÁS SZEREK „HATÁSELMÉLETE”}

A homeopátiás készítmények kiinduló anyagai (őstinktúrák) növényi nedvek, állati mérgek vagy váladékok, ásványi oldatok vagy porok. A készítmények előállítása két fő lépésből áll (lásd például NHMRC, 2015; Wikipédia, 2018):

(1) hígítás: egy lépésben minimum tízszeres (,D” sorozat), de inkább százszoros („C" sorozat); a nem is túlságosan hígított (homeopátiás szóhasználatban: nem is túlságosan erős) ,D25”-ös szer például szinte bizonyosan nem tartalmaz egyetlen hatóanyag-molekulát sem, hiszen 1 mólnyi, azaz 6 × 1023 molekulányi őstinktúrát az 1025-öd részére csökkent.

(2) minden hígítási lépés után erőteljes mechanikai behatás (rázás, dörzsölés stb.), a dinamizálás (vagy energetizálás, potenciálás) következik.

Néhány szót majd ejtek a „dinamizálás” lehetséges hatásairól is, azonban a hangsúlyt az (1)-es pontra kívánom helyezni, hiszen bárki első naiv kérdése lehet, hogy ha a gyógyítás céljából a homeopata által kijelölt készítményben legtöbbször egyáltalán nincs hatóanyag, akkor mégis hogyan lehet az hatásos. Ha belegondolunk, a sorozatos vízzel való hígítást követően azt kellene megmagyaráznunk, 
hogy hogyan gyógyít a tiszta víz! (Ráadásul attól függően különböző módon, hogy milyen őstinktúrából indultunk ki...)

A homeopátiás válasz a fenti problémára az, hogy a hígító közeg, egyszerüség kedvéért e mủben a víz, emlékszik a részecskékre, amelyeket eleinte, a hígítási sorozat kezdetén körülvett, méghozzá annál jobban (erősebben), minél többször vetették alá a hígítási-dinamizálási ciklusnak. Ez ugyan ellentmondani látszik a józan paraszti észnek, mégis, komoly tudományos szakfolyóiratok is elfogadtak már ezen érven alapuló közleményeket, lásd például (Dayenas et al., 1988).

A következőkben megpróbálom megfogalmazni, hogy hogyan is képzelhetjük el a víz „emlékezőképességét”, majd egy ezzel kapcsolatos konkrét tudományos kísérletsorozatot (Cowan et al., 2005) ismertetek röviden, amelyben felső időkorlátot adtak arra, hogy mennyire hosszú távú a tiszta, folyadék állapotú víz memóriája.

\section{NÉHÁNY GONDOLAT A TISZTA VÍZ MIKROSZKOPIKUS SZERKEZETÉVEL KAPCSOLATBAN}

E témában nem is olyan régen már megjelent egy részletes összefoglaló e lap hasábjain, Baranyai András tollából (Baranyai, 2011), így itt csak a homeopátia feltételezett „hatásmechanizmusának” szempontjából releváns információt idézem föl.

Mint ahogy azzal mindannyian szembesültünk általános és középiskolai tanulmányaink (Siposné et al., 2002, 2003) során, a víz molekulái „V”-alakúak. A „V” csúcsában egy oxigén-, a szárak végén pedig 1-1 hidrogénatom található - így jön ki a jól ismert $\mathrm{H}_{2} \mathrm{O}$ kémiai képlet. Az $\mathrm{O}$ és $\mathrm{H}$ atomokat egyszeres kovalens kötés kapcsolja össze, míg az oxigénatom rendelkezik két nemkötő elektronpárral. A nemkötő pároknak nagyobb helyigényényük van, mint a kovelens kötésékben részt vevőknek, ezért alakul ki a vízmolekula „V”-alakja. Másrészt a két nemkötő elektronpár következtében a vízmolekula „hidrogénmentes” oldalán negatív töltéstöbblet alakul ki, a „hidrogénes” oldala pedig pozitív töltésűvé válik: ezeket az ún. parciális (vagy rész-) töltéseket is szemlélteti az 1. ábra. A molekulán belüli töltésaszimmetria teszi a vízmolekulákat dipólusmolekulákká. A szomszédos vízmolekulák ellentétes töltésủ részeinek vonzó kölcsönhatását nevezi meg a 8.-os kémiakönyv annak fö okaként, hogy a víz szobahőmérsékleten folyadék (és nem gáz, mint az elemek periódusos rendszerében az oxigén körüli összes elem hidrogénnel alkotott vegyülete, mint a metán, $\mathrm{CH}_{4}$, ammónia, $\mathrm{NH}_{3}$ és a kénhidrogén, $\mathrm{H}_{2} \mathrm{~S}$ ). A vízmolekulákkal, valamint a köztük lévö kölcsönhatásokkal kapcsolatos bőséges információforrásként (Baranyai András már említett müve [Baranyai, 2011] mellett) Martin Chaplin folyamatosan bővüló internetes oldalát (Chaplin, 2018) ajánlom. 


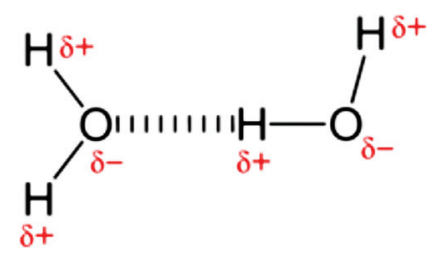

1. ábra. Hidrogénkötés kialakulása két vízmolekula között (sematikus ábrázolás, Wikipédia). Figyeljük meg, hogy a szabályos hidrogénkötésben az O...H-O szög egyenes (180ºos); ettől eltérő szögértékek energetikailag kedvezőtlenebbek.

A cseppfolyós vízben a molekulák a gázokhoz képest lényegesen szorosabban illeszkednek egymáshoz: a két szomszédos vízmolekula közötti átlagos távolság kb. $0,3 \mathrm{~nm}$ (nanométer, $10^{-9} \mathrm{~m}$, a méter egymillárdod része), ami a szilárd anyagokban fellelhető szomszédtávolságok nagyságrendjébe esik. Ennek oka az, hogy a vízmolekulák hidrogénatomjai (elektrosztatikus jellegü) vonzó kölcsönhatásba lépnek a szomszédos vízmolekula oxigénatomjához tartozó egyik nemkötő elektronpárjával. Az így kialakult kötéseket nevezzük hidrogénkötésnek, amely a vízmolekulákon belül meglévő O-H kovalens kötéseknél kb. 20-szor (Chaplin, 2018) gyengébb, ún. másodrendủ kötés (lásd 1. ábra). Amint azt Baranyai (2011) részletesen ismerteti, a víz különleges tulajdonságait a molekulák közötti hidrogénkötéseknek köszönheti.

Könnyen belátható, hogy egy vízmolekula akár négy hidrogénkötést is ki tud alakítani szomszédaival: kettôt $\mathrm{H}$ atomjain, további kettőt pedig $\mathrm{O}$ atomjának nemkötő elektronpárjain keresztül. Ezáltal, ideális esetben, minden egyes vízmolekula közel szabályos tetraéderes környezetủ lehet - ez a jég (szilárd víz) leginkább ismert kristályrácsaiban meg is valósul minden vízmolekulára. A szobahőmérsékletü cseppfolyós vízben egy molekula átlagosan kb. 3,5-3,6 hidrogénkötést képes létesíteni (Chaplin, 2018); a tökéletes (4-es) koordinációt a molekulák szakadatlan (hő)mozgása akadályozza.

A fentieket figyelembe véve H. E. Stanley és José Teixeira (1980; valamint Teixeira, 2007) munkáival összhangban megkísérelhetjük tömören megfogalmazni, miként is képzelhetjük el a cseppfolyós víz molekuláris szintủ szerkezetét. Ha minden egyes vízmolekula minden időpillanatban átlagosan több mint három hidrogénkötésben vesz részt, akkor ebböl logikusan következik, hogy tetszőleges, akár vizespohárnyi mennyiségủ vízben a hidrogénkötéseknek egy olyan hálózata alakul ki, amelynek praktikusan minden vízmolekula tagja. A tiszta víz szobahömérsékleten tehát tekinthetö végtelen, háromdimenziós hidrogénkötés-hálónak - pont, mint egy gél (lásd például kocsonya, szilikagél stb.).

Igenám, de a „víz-gél” élettartama igen rövid, mindössze pikoszekundumos $(1 \mathrm{ps}=0,000000000001$ s, 1 billiomod másodperc) nagyságrendü! Ezt többféleképpen is észlelhetjük (Cowan et al., 2005; Teixeira et al., 2006), annak alapján pél- 
dául, hogy az egy egyenesen elhelyezkedő O...H-O (vö. 1. ábra) konstellációk mind rezgési spektroszkópiai kísérletekben, mind számítógépes szimulációkban azonosíthatók; az ilyen konstellációk élettartamának felső korlátja tiszta vízben márpedig mindössze néhány pikoszekundum. A hidrogénkötések szobahömérsékleten állandóan fölbomlanak és újjászerveződnek, oly módon, hogy azok 3D hálózata minden időpillanatban észlelhető - azonban az egyedi kötések korántsem állandóak. Ezért javasolta Stanley és Teixeira (1980) a „víz mint tranziens gél” koncepciót.

A vízben oldott bármilyen anyag (például sók, alkoholok, savak, lúgok - sőt, „őstinktúrák”) perturbálják a tiszta vízre jellemző képet; ezt illusztrálja a 2. ábra bal oldala. Elektromos töltéssel rendelkező részecskék, például a sókat alkotó ionok, orientálják a környező víz dipólusmolekulákat: kationokhoz (például $\mathrm{Na}^{+}$) a vízmolekulák negatív oldala (az $\mathrm{O}$ atomok nemkötó párjai), anionokhoz (például $\mathrm{Cl}^{-}$) a pozitív oldala (a $\mathrm{H}$ atomok) kerül közel. Az ilyen módon kialakult „klaszterek" élettartama nagyságrendekkel nagyobb, mint a tiszta víz hidrogékötéseié (Teixeira, 2007), de nem tizenkét nagyságrenddel (ami ahhoz kellene, hogy akár egy teljes másodpercre stabilak legyenek).

Visszakanyarodva eredeti témánkhoz, a homeopátiás szerek hatásmechanizmusának tárgyalásához, e ponton megkísérelhetjük megfogalmazni, hogy mi is kellene ahhoz, hogy a memória effektus létezését bizonyítottnak fogadhassuk el. Az östinktúrát vízben oldva tehát valóban megváltozik a vízmolekulák elhelyezkedése, méghozzá valóban az oldott szer anyagi minőségétől függően. Ahhoz, hogy gyógyító szerként alkalmazhassunk egy (a szó legszorosabb értelmében) végtelenül hígra hígitott oldatot, arra volna szükség, hogy az őstinktúra molekulái körül az oldás során eredetileg kialakult perturbált hidrogénkötés-hálózat végtelen hosszú ideig fennmaradjon.
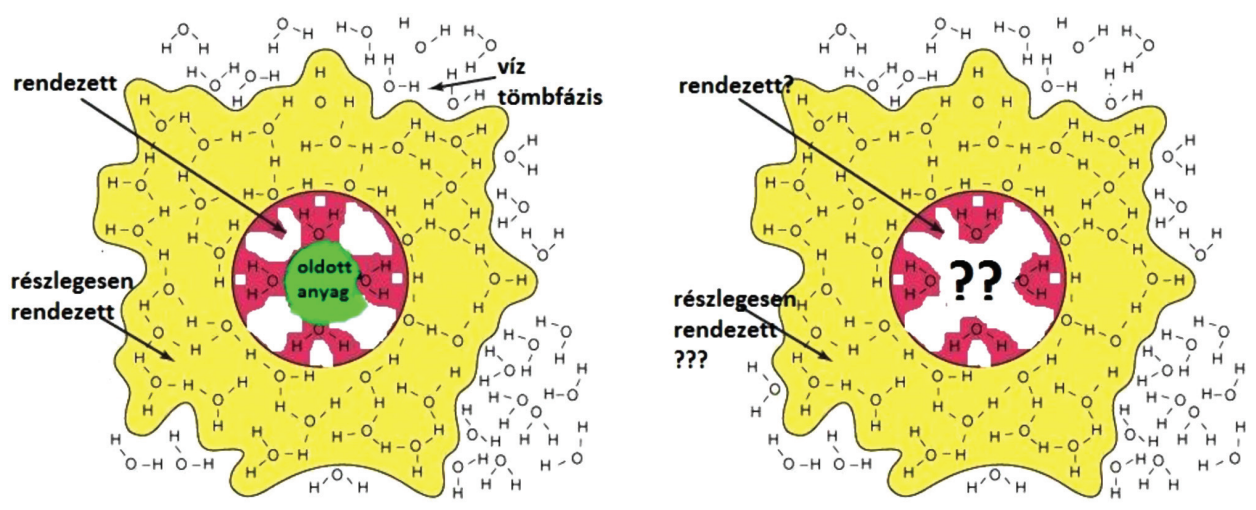

2. ábra. Bal oldali kép: vízmolekulák rendeződése pozitív töltésű oldott anyag (pl. kationok) körül. Jobb oldali kép: annak illusztrációja, hogy az oldott anyag hiányában is meg kellene maradnia ugyanannak a „vízrend”-nek, miközben a rendező erő eltűnik. (Saját szerkesztés) 
A fenti feltételt a 2. ábrán próbálom (leegyszerüsítve, 2 dimenzióban) sematikusan szemléltetni. Az oldott anyag (őstinktúra) molekulái kialakítanak maguk körül egy viszonylag állandó vízmolekula-elrendeződést (bal oldali kép). A homeopátia „hatáselmélete” szerint a sokszoros hígítást/dinamizálást követően az oldott anyag molekuláinak "hült helye" körül is meg kellene maradnia ugyanannak a vízmolekula-elrendeződésnek: ezt jelentené a „memória effektus”. A következő fejezetben ennek lehetőségével (illetve inkább lehetetlenségével) foglalkozunk - attól a nyugtalanító kérdéstől eltekintve, hogy mi is történik pontosan az oldott anyag hült helyével. (A szerző primitív logikájának megfelelően ugyanis a vízmolekulák eredeti elrendeződése csak úgy maradhat fent, ha az oldószermolekulák helye nem töltődik ki vízmolekulákkal.)

\section{EGY PERDÖNTŐ KÍSÉRLET: \\ ULTRAGYORS MEMÓRIAVESZTÉS TISZTA, FOLYADÉK ÁLLAPOTÚ H 20 -BAN}

A Michael L. Cowan és munkatársai által végzett kísérletsorozatban (Cowan et al., 2005) a fent leírt szituációt tiszta vízben olyan módon szimulálták, hogy egyegy hidrogénkötés környezetét energiaközléssel perturbálták (azzal analóg módon, ahogy egy oldott molekula teszi), majd megpróbálták megmérni, hogy az adott környezettel közölt energia mennyi ideig marad lokalizált.

A kísérletet a maguk által kifejlesztett kétdimenziós infravörös spektroszkópia (Cowan et al., 2004) módszerével végezték, a szintén maguk által létrehozott mérőmüszeren. A standard infravörös spektroszkópiát az 1950-es évektől alkalmazzák analitikai célokra, azonban ahhoz, hogy a tiszta folyadék $\mathrm{H}_{2} \mathrm{O}$-ban kaphassunk részletes, molekuláris szintủ információt, a technikát jó fél évszázadon át kellett folyamatosan finomítani. A kétdimenziós (2D) infravörös spektroszkópia minden aspektusát részletesen tárgyalja például Peter Hamm és Martin Zanni (2011) kézikönyve.

Az infravörös spektroszkópia (amelyhez egy általános szövegkönyv lehet például Stuart et al., 1996) a molekulák rezgéseire érzékeny kísérleti módszer. A vízmolekula lehetséges molekularezgései (Chaplin, 2018) közül nekünk most az O-H kovalens kötés mentén történő nyújtás a legfontosabb: ennek frekvenciája jó közelítéssel $100 \mathrm{THz}$ (terahertz, $1 \mathrm{THz}$ másodpercenként $10^{12}$ rezgést jelent), hullámhossza kb. 3 mikrométer (a spektroszkópusok által kedvelt hullámszám-egységekben ez $3350 \mathrm{~cm}^{-1}$-nek felel meg). A molekularezgések igen érzékenyek a hömérsékletre és a szóban forgó kötés környezetére: az említett értékek szobahömérsékleten érvényesek folyadék (könnyü) vízben $\left(\mathrm{H}_{2} \mathrm{O}\right)$, azaz olyan vízmolekulákra, amelyek hidrogénkötéses környezetben találhatóak.

Cowan és munkatársai munkájában (2005) a vízmolekulák O-H kötéseit a rájuk jellemző molekularezgések frekvenciájának (kb. 100 THz) megfelelő igen rö- 
vid (70 fs, azaz femtoszekundomos, $1 \mathrm{fs}=10^{-15}$ másodperc) infravörös impulzusokkal gerjesztették, majd a gerjesztést követö 100 fs alatt követték az infravörös elnyelés (IR-abszorpció) mértékét.

Egy ilyen mértékủ gerjesztés modellezheti azt a perturbációt, amelyet a tiszta víz hidrogénkötés-rendszerében a beoldott részecskék (például az „őstinktúra" ionjai, molekulái) idéznek elő. Amennyiben a tiszta víznek (ami, emlékezzünk, gyakorlatilag az összes homeopátiás szer „hatóanyaga”) legalább 100 fs-os memóriája volna, úgy a gerjesztés pillanatában mért IR-abszorpciót kellett volna mérni a gerjesztés után 100 fs múlva is. Cowanék ezzel szemben azt találták (lásd Cowan et al., 2005 4. ábráját), hogy a gerjesztés által létrehozott perturbált állapotnak már csak maradványai vannak 50 fs eltelte után, 100 fs-nál pedig már nyomai sem. Azaz legkésőbb a perturbáció megszüntetését (kikapcsolását) követő 0,000 0000000001 másodperc $\left(10^{-13} \mathrm{~s}\right)$ múlva visszaáll a tiszta vízre jellemző, perturbálatlan egyensúlyi szerkezet - a tiszta víz emlékezőtehetségének, vagy mondjuk úgy, „rövid távú memóriájának” tehát jelenleg ez a felső korlátja.

A fenti kísérleti eredményeket Cowan és munkatársai úgy értelmezték, hogy a gerjesztés megszűnését követően a rendszerrel közölt energia a víz hidrogénkötéseinek segítségével, azok mentén oszlik szét rendkívül hatékonyan. Azaz, a homeopátiás szerek feltételezett hatásmechanizmusának szempontjából paradox módon, éppen azon sajátsága teszi lehetetlenné a víz hosszú távú memóriájának kialakulását, amelynek különleges képességeit (szobahőmérsékleten folyadék mivoltát, a $277 \mathrm{~K}$-en jelentkező sürüségmaximumot stb. [Baranyai, 2011]; végső soron az élet kialakulásában és fennmaradásában játszott kulcsszerepét) köszönheti.

Megjegyzem, hogy Cowan és szerzőtársai (2005) esetleg a homeopátia kérdéskörétől nem teljesen függetlenül választották az Ultragyors memóriavesztés és energia-újraelosztás a cseppfolyós $\mathrm{H}_{2} \mathrm{O}$ hidrogénkötés-hálózatában címet... (bár a müben maga a 'homeopátia' kifejezés nem jelenik meg).

\section{ÖSSZEFOGLALÁS ÉS KITEKINTÉS; A „DINAMIZÁLÁSI” LÉPÉS LEHETSÉGES KÖVETKEZMÉNYEI}

Leszögezhetjük tehát, többek között Michael Cowan (Cowan et al., 2005) és José Teixeira (Teixeira, 2007) publikációi alapján, hogy miután a tiszta víz emlékezötehetsége (kis jóindulattal) maximum 0,000 0000000001 másodpercig terjed, a homeopátiás szerek (leginkább csak feltételezett, lásd NHMRC, 2015) hatását semmiképpen nem magyarázhatjuk ,memória effektussal”.

Ezen a ponton akár le is zárhatnánk e diskurzust - azonban talán érdemes itt is megismételni Teixeira (2007) okfejtését a „dinamizálás” lehetséges hatásait 
illetően. Hiszen igaz ugyan, hogy egy (például) „D25”-ös homeopátiás szerben az eredeti őstinktúrának már egyetlen molekulája sem található, viszont ne feledjük, hogy ugyanennek a szernek az elöállítása során 25-ször vetik az (egyre híguló) oldatot „erős mechanikai beavatkozás”, azaz rázás, dörzsölés stb. hatása alá. Ezen folyamat közben a szer erős kölcsönhatásba kerül a tartó/feldolgozó edények falával, valamint a levegővel (és/vagy esetleg egyéb gázhalmazállapotú anyagokkal, a receptúra függvényében). Ilyen módon az elkészült homeopátiás szer valószínűleg mégsem egészen tiszta víz, hanem a híguló oldattal érintkezésbe került felületekböl és gázokból beoldódott anyagok nagyon híg oldata. Amennyiben tehát a homeopátiás szereknek a placebohatáson túli hatásmechanizmusát kívánja valaki tudományos alapon magyarázni, az elő́llítás körülményeit (és azok következményeit) az eddigieknél lényegesen részletesebben kellene elemezni.

\section{IRODALOM}

Baranyai A. (2011): A víz fizikai kémiája. Magyar Tudomány, 172, 12, 1459-1466. http://www. matud.iif.hu/2011/12/06.htm

Chaplin, M. (2018): Water Structure and Science. http://wwwl.1sbu.ac.uk/water/water_structure_science.html (Legutóbb frissítve: 2018. szeptember 6.)

Cowan, M. L. - Bruner, B. D. - Huse, N. et al. (2005): Ultrafast Memory Loss and Energy Redistribution in the Hydrogen Bond Network of Liquid $\mathrm{H}_{2} \mathrm{O}$. Nature, 434, 199-202. DOI: 10.1038/ nature 03383 , https://www.nature.com/articles/nature 03383

Cowan, M. L. - Ogolvie, J. P. - Miller, R. J. D. (2004): Two-dimensional Spectroscopy Using Diffractive Optics Based Phased-locked Photon Echoes. Chemical Physics Letters, 434, 199202. DOI: 10.1016/j.cplett.2004.01.027

Dayenas, E. - Beauvais, F. - Amara, J. et al. (1988): Human Basophil Degranulation Triggered by Very Dilute Antiserum against IgE. Nature, 333, 816-818. DOI: 10.1038/333816a0, https://bit. ly/2wK6edO

EASAC (2017): Homeopathic Products and Practices. Assessing the Evidence and Ensuring Consistency in Regulating Medical Claims in the EU. https:/easac.eu/publications/details/ homeopathic-products-and-practices/

Fábián I. (2017): Csodavizek, csodasók. MTA Videó (MTÜ 2017.11.08.). https://www.youtube. com/watch? $=$ szLrKfPIQRY

Hamm, P. - Zanni, M. (2011): Concepts and Methods of 2D Infrared Spectroscopy. Cambridge University Press. DOI: 10.1017/CBO9780511675935

NHMRC (2015): National Health and Medical Research Council. 2015. NHMRC Information Paper: Evidence on the Effectiveness of Homeopathy for Treating Health Conditions. Canberra, Australia. ISBN Online: 978-1-925129-29-8. www.nhmrc.gov.au/guidelines-publications/ cam02

Dr. Siposné Dr. Kedves É. - Horváth B. - Péntek L. (2002): Kémia 9. Általános kémia. Szeged: Mozaik Kiadó

Dr. Siposné Dr. Kedves É. - Horváth B. - Péntek L. (2003): Kémia 8. Szervetlen kémia. Szeged: Mozaik Kiadó 
Stanley, H. E. - Teixeira, J. (1980): Interpretation of the Unusual Behavior of $\mathrm{H}_{2} \mathrm{O}$ and $\mathrm{D}_{2} \mathrm{O}$ at Low Temperatures: Tests of a Percolation Model. The Journal of Chemical Physics, 73, 3404-3423. DOI: $10.1063 / 1.440538$

Stuart, B. H. - George, B. - McIntyre, P. (1996): Modern Infrared Spectroscopy. Wiley

Teixeira, J. (2007): Can Water Possibly Have a Memory? A Sceptical View. Homeopathy, 96, 158-162. DOI: 10.1016/j.homp.2007.05.001

Teixeira, J. - Luzar, A. - Longeville, S. (2006): Dynamics of Hydrogen Bonds: How to Probe Their Role in the Unusual Properties of Liquid Water. Journal of Physics: Condensed Matter, 18, S2353-S2362.

Wikipédia (2018): Homeopátia. https://hu.wikipedia.org/wiki/Homeop\%C3\%Altia (Legutóbb frissítve: 2018. augusztus 7.) 